\title{
14. ORIGIN OF ASPHALT AND ADJACENT OIL STAINS IN LOWER CRETACEOUS FRACTURED LIMESTONES, DEEP SEA DRILLING PROJECT LEG 771
}

\author{
James G. Palacas, J. David King, and George E. Claypool, U.S. Geological Survey, \\ Box 25046, Federal Center, Denver, Colorado \\ and \\ Leslie B. Magoon, U.S. Geological Survey, 3475 Deer Creek Rd., Palo Alto, California
}

\begin{abstract}
Analyses of extractable organic matter from selected core samples obtained at DSDP Site 535 in the eastern Gulf of Mexico show that the asphalt (or tar) and adjacent oil stains in Lower Cretaceous fractured limestones have a common origin and are not derived from the surrounding organic-matter-rich limestones. Organic matter indigenous to those surrounding limestones was shown to be thermally immature and incapable of yielding the hydrocarbon mixture discovered. In contrast, the oil-stained and asphaltic material appears to be a post-migration alteration product of a mature oil that has migrated from source rocks deeper in the section, or from stratigraphically equivalent but compositionally different source-facies down-dip from the drill site. Further, hydrocarbons of the altered petroleum residues were shown to be similar to Sunniland-type oils found in Lower Cretaceous rocks of South Florida. The results suggest that shallowwater, platform-type source-rock facies similar to those that generated Sunniland-type oils, or deeper-water facies having comparable oil-generating material, are present in this deep-water $(>3000 \mathrm{~m})$ environment. These findings have important implications for the petroleum potential in the eastern Gulf of Mexico and for certain types of deep-sea sediments.
\end{abstract}

\section{INTRODUCTION}

At Site 535, core drilling penetrated a sequence of Lower Cretaceous (Valanginian to Hauterivian) light-colored, commonly bioturbated organic-matter-lean limestones and dark, commonly laminated organic-matterrich limestones and marlstones (organic carbon as much as $10 \%$ or more). This sequence of rocks contained a 55-m interval (530-585 m sub-bottom) characterized by asphalt-filled fractures and adjacent oil-stained halos in the limestone. Site 535 is in the Straits of Florida (Fig. 1) about midway between the Campeche and Florida escarpments, in $3450 \mathrm{~m}$ of water. This chapter describes the results of geochemical analyses of the asphalt and adjacent oil stains and extractable organic matter indigenous to the surrounding host rocks. The major questions addressed are as follows.

1. Are the asphalt and oil stains derived from the adjacent organic-matter-rich limestones or from some other source-rock?

2. Are the asphalt and oil stains thermally immature bitumen deposits or postmigration alteration products of a mature crude oil?

To answer these questions, conventional petroleumsource-rock geochemical analyses were performed, including carbon isotope ratios and detailed molecular analyses of biomarker compounds by computerized gas chromatography-mass spectrometry.

\section{SAMPLES AND EXPERIMENTAL PROCEDURES}

The stratigraphic positions of the samples analyzed for this report are indicated on Figure 2. A brief description of each sample is given

\footnotetext{
${ }^{1}$ Buffler, R. T., Schlager, W., et al., Init. Repts. DSDP, 77: Washington (U.S. Govt. Printing Office).
}

in Table 1. Figure 3 is a photograph of a core section, illustrating the relationship of the asphalt-filled fractures and adjacent oil stains to the surrounding (unstained) rock.

Carbonate carbon was determined by digestion of the powdered rock with boiling phosphoric acid and gas-chromatographic determination of the evolved $\mathrm{CO}_{2}$. Organic carbon was calculated as the difference between carbonate carbon and total carbon (determined on a LECO induction furnace).

Powdered rock samples were extracted with redistilled chloroform in a Soxhlet apparatus. Elemental sulfur was removed by refluxing with activated copper strips. The isolated extract was deasphaltened with heptane and then separated on an alumina-silica gel column into three fractions: saturated hydrocarbons or alkanes, (eluted in heptane), aromatic hydrocarbons (eluted in benzene), and resins (eluted in a mixture of $50-50$ benzene-methanol).

The alkane fraction was analyzed by capillary gas chromatography (GC) using a Hewlett-Packard 5880 gas chromatograph equipped with a $30 \mathrm{~m} \times 0.32 \mathrm{~mm}$ SE-30 fused-silica capillary column and flame ionization detector. Instrument conditions were $25 \mathrm{~cm} / \mathrm{s}$ helium carrier flow, splitless injection at $325^{\circ} \mathrm{C}$, FID detector at $350^{\circ} \mathrm{C}$. The column temperature was programmed from 50 to $300^{\circ} \mathrm{C}$ at $6^{\circ} \mathrm{C} / \mathrm{min}$.

Molecular structures of the cycloalkanes were determined by gas chromatographic-mass spectrometric (GC-MS) magnetic scan. The relative distributions of the various terpanoid structural types were determined by GC-MS multiple ion detection (MID). A Hewlett-Packard 5880 gas chromatograph directly coupled to a Kratos MS-30 mass spectrometer was used for all GC-MS analyses. The 5880 was equipped with a $50 \mathrm{~m} \times 0.32 \mathrm{~mm}$ SE- 54 fused-silica capillary column, $25 \mathrm{~cm} / \mathrm{s}$ helium carrier flow, and splitless injection via HP7671A automatic sampler. The column temperature was programmed from 100 to $340^{\circ} \mathrm{C}$ at $4^{\circ} \mathrm{C} / \mathrm{min}$.

The mass spectrometer source-pressure was $1 \times 10^{-6}$ torr at $250^{\circ} \mathrm{C}$ operated in E. I. mode at $70 \mathrm{eV}$; dynamic mass resolution was 1200 . Magnetic exponential downscan was 1 second per mass decade, and multiple ion detection was accomplished by accelerating voltage switching at a constant magnetic field.

The ${ }^{13} \mathrm{C} /{ }^{12} \mathrm{C}$ ratios of the saturated and aromatic hydrocarbon fractions were determined on a Finnigan-MAT mass spectrometer. The hydrocarbon fractions were converted to $\mathrm{CO}_{2}$ by combustion under oxygen, with subsequent purification in a high-vacuum system. The ${ }^{13} \mathrm{C} /$ ${ }^{12} \mathrm{C}$ ratios are expressed in the usual notation,

$$
\delta^{13} \mathrm{C}(\% 0)=\left\{\left[\left({ }^{13} \mathrm{C} /{ }^{12} \mathrm{C}\right)_{\text {sample }} /\left({ }^{13} \mathrm{C} /{ }^{12} \mathrm{C}_{\mathrm{PDB}}\right)\right]-1\right\} \times 10^{3}
$$




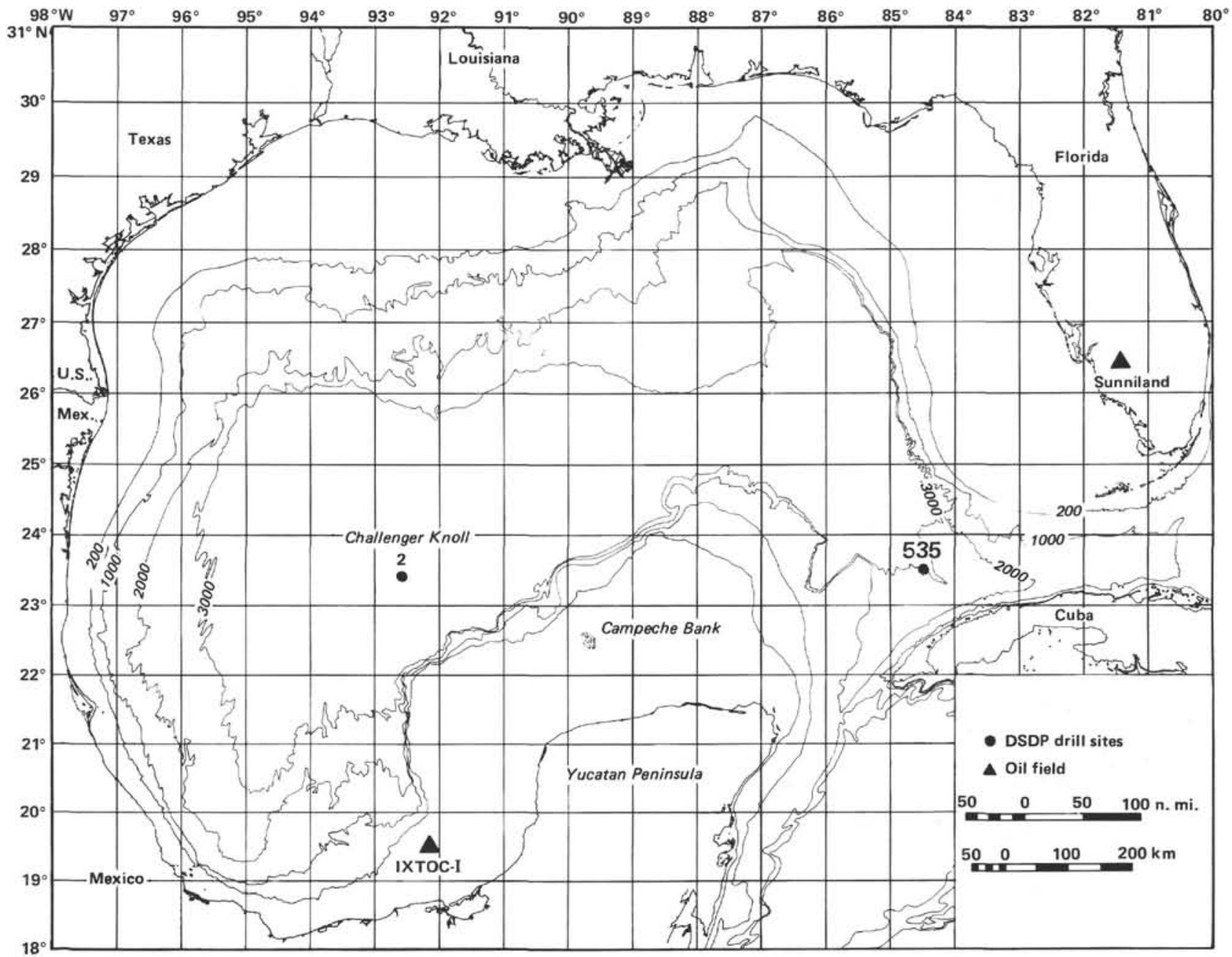

Figure 1. Map showing the location of Site 535. Also shown are the source sites of three crude-oil samples (Sunniland, Challenger Knoll, and IXTOC-I) used in this report for comparative purposes. Bathymetric contours are in meters.

\section{RESULTS}

Contents of organic carbon (TOC), carbonate carbon, extractable organic matter (EOM), and hydrocarbon fractions are reported in Table 2, along with the $\delta^{13} \mathrm{C}$ values of the saturated and aromatic hydrocarbon fractions. Capillary-column gas chromatographic analyses of the $\mathrm{C}_{15}+$ saturated hydrocarbons (alkanes) are shown in Figure 4. GC-MS analyses of tricyclic diterpanes, pentacyclic triterpanes, and steranes of alkane extracts from two representative unstained samples and from an oil-stained sample (which is essentially identical to the asphalt sample) are illustrated in Figures 5, 6, and 7, respectively, with compound/peak identifications keyed to Tables 3 and 4 .

The alkane distributions of the four samples of surrounding rocks that are unstained are characterized by a bimodal distribution with a minimum in the $n-\mathrm{C}_{25}$ region, a similar $n$-alkane distribution with no obvious odd or even carbon number predominance at least up to $n-\mathrm{C}_{25}$, and a similar rich and complex assemblage of branched-cyclic compounds in the sterane-triterpane re- gion. Another diagnostic feature of the unstained rock extracts is the presence of an abundance of branched-cyclic compounds in the region between $\mathrm{C}_{17}$ and $\mathrm{C}_{25}$ and a generally higher proportion of the isoprenoids, pristane (Pr.) and phytane (Ph.), relative to the linear $n$-alkanes. The average ratio of these compounds in extracts of the four unstained samples is $\mathrm{Pr} . / n-\mathrm{C}_{17}=1.22, \mathrm{Ph} . / n$ $\mathrm{C}_{18}=1.97$, and $\mathrm{Pr} . / \mathrm{Ph} .=1.05$ (Table 2).

On the other hand, the overall $\mathrm{C}_{15}+$ alkane distribution of the two oil-bearing samples (Fig. 4) is decidedly different from that of the unstained samples. The alkanes in the stained samples differ in the following respects: (1) the relative concentration of the higher-molecular-weight components beyond the $n-C_{26}$ region exceeds that of the lower-molecular-weight components below $n-C_{20}$, whereas the reverse is true for the unstained samples; (2) the sterane-triterpane distribution is less complex than in the unstained samples; (3) there are fewer branched-cyclic components in the $\mathrm{C}_{17}-\mathrm{C}_{25}$ region, compared with the unstained samples; (4) above $n-C_{20}$ the $n$-alkanes are notably absent or very scarce in the stained samples but abundant in the unstained sam- 


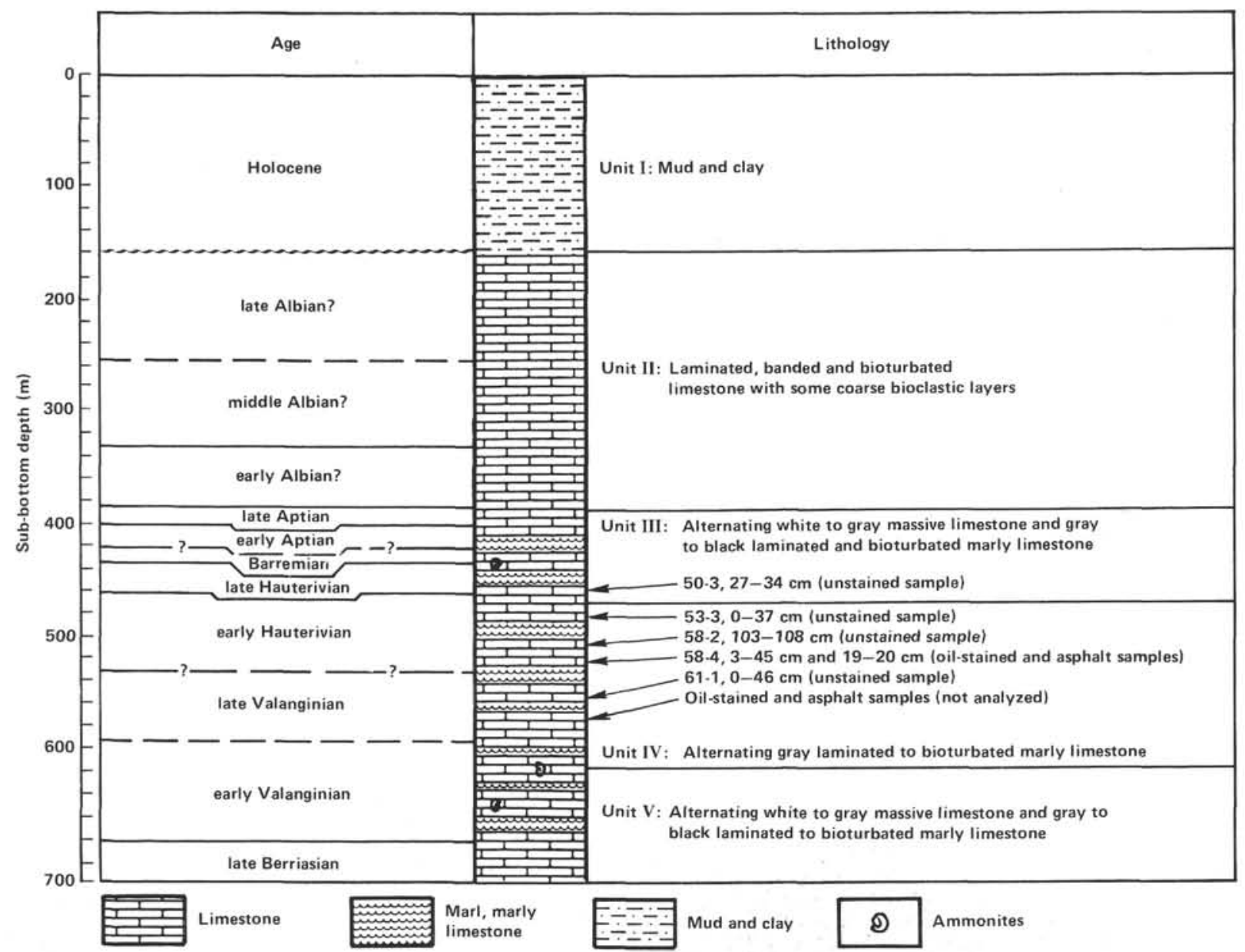

Figure 2. Stratigraphic summary for Hole 535 and positions from which were taken the unstained and oil-stained core samples analyzed from the interval 458 to $530 \mathrm{~m}$ sub-bottom. The position of the deepest oil-stained limestone and asphalt deposits encountered is also indicated at $585 \mathrm{~m}$ sub-bottom. Water depth $=3450 \mathrm{~m}$.

Table 1. Sub-bottom depths (m) and lithologic descriptions of Lower Cretaceous samples, (Hole 535).

\begin{tabular}{|c|c|c|c|}
\hline $\begin{array}{l}\text { Core-Section } \\
\text { (interval in } \mathrm{cm} \text { ) }\end{array}$ & $\begin{array}{l}\text { Sub-bottom } \\
\text { depth }\end{array}$ & $\begin{array}{l}\text { Sample } \\
\text { type }\end{array}$ & Description \\
\hline $50-3,27-34$ & 458.3 & Unstained rock & Laminated marlstone \\
\hline $53-3,0-37$ & 480.6 & Unstained rock & Light gray laminated limestone \\
\hline $58-2,103-108$ & 527.3 & Unstained rock & $\begin{array}{l}\text { Dark gray laminated, argillaceous } \\
\text { limestone }\end{array}$ \\
\hline $58-4,3-46$ & 529.8 & Oil-stained rock & $\begin{array}{l}\text { Light gray laminated limestone } \\
\text { with oil stain }\end{array}$ \\
\hline $58-4,19-20$ & 529.8 & Asphalt vein & $\begin{array}{l}\text { Brownish-black asphalt filling } \\
\text { fractured limestone }\end{array}$ \\
\hline $61-1,0-46$ & 552.5 & Unstained rock & $\begin{array}{l}\text { Dark gray laminated, argillaceous } \\
\text { limestone }\end{array}$ \\
\hline
\end{tabular}

ples; and (5) the ratios $\mathrm{Pr} . / n-\mathrm{C}_{17}(0.72)$ and $\mathrm{Ph} . / n-\mathrm{C}_{18}$ $(0.72)$ are significantly lower than those in the unstained samples (Table 2).

To elucidate the molecular distribution of the polycyclic alkane biomarker compounds, tricyclic and pentacyclic terpane and sterane distribution patterns were determined by computerized GC-MS analysis.

Selected ion mass fragmentograms at $\mathrm{m} / z=191$ show the distribution of the more prominent tricyclic diterpanes that range from $C_{19}$ (molecular weight 262) to $C_{28}$ (molecular weight 378) (Fig. 5), although the full complement of tricyclics may extend up to $\mathrm{C}_{45}$ (Moldowan et al., 1983). Distinct differences between the oil-bearing samples and the unstained samples are immediately apparent in the tricyclic patterns. For example, the oilbearing samples are characterized by a simple distributional pattern with a distinctive high $\mathrm{C}_{23}$ peak (molecular weight 318 ) and subordinate amounts of the other tricyclics. In sharp contrast, the indigenous soluble organic matter of the unstained samples is characterized by a more complex sequence of $\mathrm{m} / z=191$-generating compounds which include not only the more common $\mathrm{C}_{19}-\mathrm{C}_{28}$ tricyclic homologs, but also many other unidentified tricyclic terpane isomers and tetracyclic terpanes.

Figure 6 shows the pentacyclic triterpane distributions as determined by $\mathrm{m} / z=191$ mass fragmentograms. Again, as in the tricyclic distribution patterns, the pentacyclic pattern for the oil-bearing samples is unequivocally dissimilar to the pentacyclic patterns in the unstained samples. For example, the following compounds are present in the unstained samples but absent in the oil-bearing samples: (1) a homologous series of $17 \beta$, $21 \beta$ hopanes occurring at least from $\mathrm{C}_{30}$ to $\mathrm{C}_{33}$ (peaks $15,18,21$, and 24 , Fig. $6 \mathrm{C}$ and Table 3 ); (2) numerous unsaturated hopanoids (hopenes) at peaks 1, 7, 9, and 11 , and probably other hopenes either not identified or 


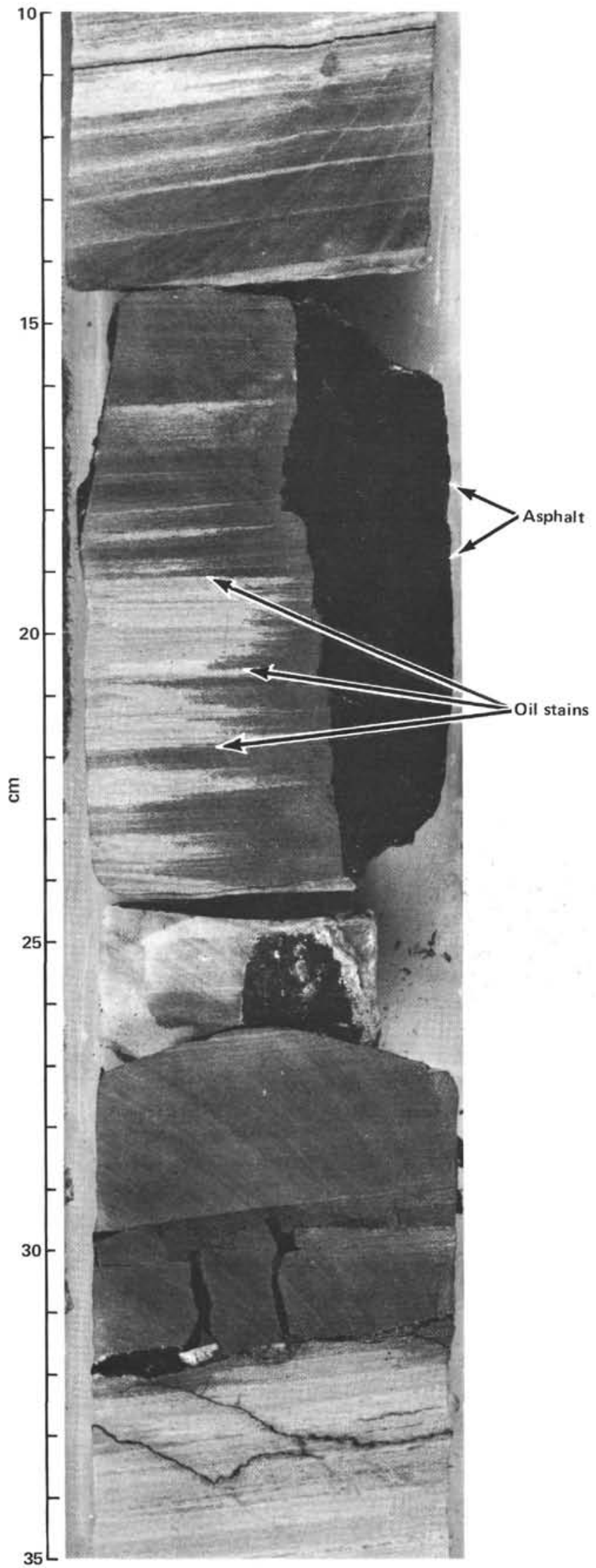

Figure 3. Core photograph of the interval 535-58-4, 10-35 cm from Hole 535, showing solid asphalt-filled fractures and oil stains. masked by other hopanes; and (3) a clustered series of $\mathrm{C}_{30}$ non-hopanoid pentacyclics at peaks 2,4 , and 6 . In addition, the unstained samples seem to lack or have only trace amounts of the nearly ubiquitous $18 \alpha$ (peak 3) and $17 \alpha$ (peak 5) trisnorhopanes (Figs. 6A and 6C) which, on the other hand, are present in the oil-stained sample (Fig. 6B). Another significant difference that should be noted in the unstained samples is the very low ratio of the diastereoisomeric $(22 \mathrm{~S} / 22 \mathrm{R})$ homopanes (peaks 13 and 14, Fig. 6C). For example, in Sample 535$61-1,0-46 \mathrm{~cm}$ the $22 \mathrm{~S} / 22 \mathrm{R}$ ratio $=0.23$, as opposed to 1.34 in the oil-stained sample $(535-58-4,3-46 \mathrm{~cm})$.

In the sterane mass-fragmentogram patterns in Figure 7 , another striking difference occurs between stained and unstained samples. The unstained samples are characterized by a simple distribution that consists principally of a regular sequence of alternating $5 \beta, 14 \alpha$ steranes and $5 \alpha, 14 \alpha$ steranes and the notable absence of the $5 \alpha$, $14 \beta$ steranes. In contrast, the $5 \alpha, 14 \beta$ steranes are present and the $5 \beta, 14 \alpha$ steranes are absent or present in low concentrations in the oil-bearing samples. Furthermore, the oil-stained samples also contain numerous other rearranged and regular steranes not present in the unstained samples (Fig. 7 and Table 4).

The $\delta^{13} \mathrm{C}$ values of the extractable hydrocarbon fractions show similar groupings. The asphalt and the oilstained samples have $\delta^{13} \mathrm{C}$ of $-26.5 \pm 0.1 \%$ for the saturates and $-25.8 \pm 0.1 \%$ for the aromatics. Comparable $\delta^{13} \mathrm{C}$ values for the unstained rocks are from 1.8 to $2.3 \%$ more negative in the saturate fraction and 2.8 to $3.9 \%$ more negative in the aromatic fraction (Table 2).

\section{DISCUSSION}

On the basis of conventional GC and computerized GC-MS molecular analyses, two types of hydrocarbon mixtures are present in the Site 535 samples studied. The unstained rock samples (Figs. 4-7) all have similar general characteristics, and are comparable in most respects to other organic-matter-rich limestones cored by DSDP that are interpreted to be thermally immature (Dean et al., 1981; Comet et al., 1981). The asphalt and the adjacent oil stains (Figs. 4-7) are nearly identical to each other, indicating that they are genetically related, and contain a hydrocarbon mixture completely different from that in the unstained rocks.

The differences between these two types of hydrocarbon mixtures are consistent with the interpretation that the unstained rocks contain hydrocarbons indigenous to the thermally immature limestone sequence, whereas the asphalt and the oil-stained rock contain hydrocarbons similar to those in crude oils from relatively mature carbonate sequences. Evidence for the thermal immaturity of the hydrocarbons in the unstained rocks is summarized in the following:

1. The presence of the less stable $\mathrm{C}_{27}, \mathrm{C}_{28}$, and $\mathrm{C}_{29}$ sterenes with double bonds at either the $\Delta^{5,6}$ position or the $\Delta^{13,17}$ position (Fig. 8) (Rubenstein et al., 1975; Giger and Schaffner, 1981).

2 . The presence of the less stable $17 \beta(\mathrm{H}), 21 \beta(\mathrm{H})$ hopanes (peaks 15, 18, 21, and 24; Figs. 6A and 6C) (Seifert and Moldowan, 1980). 
Table 2. Organic geochemical data of Lower Cretaceous samples, Hole 535.

\begin{tabular}{|c|c|c|c|c|c|c|c|c|c|c|c|c|c|c|}
\hline \multirow{2}{*}{$\begin{array}{l}\text { Core-Section } \\
\text { (interval in cm) }\end{array}$} & \multirow{2}{*}{$\begin{array}{c}\text { Sample } \\
\text { description }\end{array}$} & \multirow{2}{*}{$\begin{array}{l}\text { Total } \\
\text { carbonate } \\
\text { content } \\
\text { (wt. \%) }\end{array}$} & \multirow{2}{*}{$\begin{array}{c}\text { TOC } \\
\text { (wt. \%) }\end{array}$} & \multirow{2}{*}{$\begin{array}{l}\text { EOM } \\
(\mathrm{ppm})\end{array}$} & \multicolumn{2}{|c|}{$\begin{array}{l}\text { Percent } \\
\text { of EOM }\end{array}$} & \multirow{2}{*}{$\begin{array}{l}\frac{\text { EOM }}{\text { TOC }} \\
(\%)\end{array}$} & \multirow{2}{*}{$\frac{\text { Sat. }}{\text { Arom. }}$} & \multirow{2}{*}{$\frac{\text { Pr. }}{n-\mathrm{C}_{17}}$} & \multirow{2}{*}{$\frac{\text { Ph. }}{n-C_{18}}$} & \multirow{2}{*}{$\frac{\mathrm{Pr} .}{\mathrm{Ph} .}$} & \multirow{2}{*}{$\begin{array}{l}C_{31} \\
S / R\end{array}$} & \multicolumn{2}{|c|}{$\begin{array}{c}{ }^{{ }^{13} \mathrm{C}\left(\%_{0}\right.} \\
\text { versus PDB })^{\mathrm{a}}\end{array}$} \\
\hline & & & & & $\mathrm{HC}$ & Non-HC & & & & & & & Sat. & Arom. \\
\hline $50-3,27-34$ & Unstained & 25.0 & $3.7-7 x-10$ & 1220 & 35.0 & 65.0 & 3.3 & 0.84 & 0.98 & 1.31 & 1.16 & 0.25 & - & -29.7 \\
\hline $53-3,0-37$ & Unstained & 76.6 & 1.5 & 575 & 24.7 & 75.3 & 3.8 & 0.35 & 1.17 & 2.17 & 0.98 & 0.12 & - & -28.7 \\
\hline $58-2,103-108$ & Unstained & 55.8 & 3.1 & 1730 & 23.1 & 76.9 & 5.6 & 0.37 & 0.88 & 1.48 & 1.15 & 0.16 & -28.3 & -28.6 \\
\hline $58-4,3-46$ & Oil-stained & 86.6 & 1.5 & 17,000 & 40.7 & 59.3 & 113.0 & 0.10 & 0.72 & 0.72 & 1.16 & 1.34 & -26.4 & -25.7 \\
\hline $58-4,19-20$ & Asphalt & ND & ND & ND & 47.8 & 52.2 & ND & 0.15 & ND & ND & ND & 1.60 & -26.5 & -25.8 \\
\hline $61-1,0-46$ & Unstained & 67.5 & 4.7 & 1840 & 24.1 & 75.9 & 3.9 & 0.32 & 1.85 & 2.93 & 0.89 & 0.23 & -28.8 & -28.6 \\
\hline
\end{tabular}

Note: $\mathrm{TOC}=$ total organic carbon; $\mathrm{EOM}=$ extractable organic matter; $\mathrm{HC}=$ hydrocarbons (saturated hydrocarbons [Sat.] plus aromatic hydrocarbons

[Arom.]); $\mathrm{Pr}$. = pristane; $\mathrm{Ph} .=$ phytane; $\mathrm{C}_{31} \mathrm{~S} / \mathrm{R}=$ ratio of $22 \mathrm{~S}$ to $22 \mathrm{R}$ diastereoisomers of the $\mathrm{C}_{31}$ extended hopane (homohopane); ND = not

determined; $-=$ no analysis performed: sample exhausted in previous analyses.

a Reference samples: NBS-22 $=-29.4 ;$ NBS-21 $=-28.0$

3. The presence of the less stable hopenes (peaks 1 , 7, 9, and 11; Figs. 6A and 6C) (Barnes et al., 1979).

4. The presence of only $14 \alpha(\mathrm{H})$ steranes or, conversely, the absence of $14 \beta(\mathrm{H})$ steranes, which are construed to be a product largely of increasing maturation (Fig. 7) (Seifert and Moldowan, 1981).

5. The low diastereoisomeric ratios of the extended hopanes, such as the $\mathrm{C}_{31} 22 \mathrm{~S} / 22 \mathrm{R}$ ratio, which ranges from 0.12 to 0.25 and averages 0.19 (peaks 13/14, Fig. $6 \mathrm{C}$ and Table 2). Ratios less than about 1.0 to 1.2 are considered immature (Ensminger et al., 1977; Seifert and Moldowan, 1980).

In contrast, the hydrocarbons from the asphalt and the oil-stained samples are characterized by molecular compositions essentially opposite to or significantly different from those described above. For example, the less stable $\mathrm{C}_{27}, \mathrm{C}_{28}$, and $\mathrm{C}_{29}$ sterenes (Fig. 8), the $\beta, \beta$ hopanes (peaks 15, 18, 21, and 24; Figs. 6A and 6C), and the hopenes (peaks 1, 7, 9, and 11; Figs. 6A and 6C) are either absent or present only in trace quantities in the oil-bearing samples. Further, the oil-bearing samples have typical mature molecular ratios in the extended hopane series (Table 1; e.g., $C_{31} 22 \mathrm{~S} / 22 \mathrm{R}=1.34-1.60$ ) (Seifert and Moldowan, 1980) and in the $\mathrm{C}_{29}$ sterane series (Fig. 7; e.g., $5 \alpha, 14 \beta, 17 \beta /[5 \alpha, 14 \alpha, 17 \alpha+5 \alpha, 14 \beta$, $17 \beta]$ or peaks $24 \mathrm{a}+\mathrm{b} /[22+25+24 \mathrm{a}+\mathrm{b}] \simeq 0.55$ ) (Mackenzie et al., 1983). All the above combined data show that the fracture-related hydrocarbons originate at a much higher level of thermal maturity, and dictate against the surrounding bituminous limestones as a source of the asphalt and the oil in the stained rock. This conclusion confirms a similar interpretation arrived at by Katz (1982), who studied the same carbonate section from DSDP Site 535.

The question still remains as to what is the source of the oil and asphalt. Comparison of all three biomarker patterns (tricyclic, sterane, and pentacyclic) of the oilstained sample with the same patterns of a commercial crude oil reservoired in the Lower Cretaceous Sunniland Limestone on the onshore portion of the South Florida Basin (Palacas, 1983) shows that they are similar (Fig. 9), except for the $17 \alpha(\mathrm{H}), 18 \alpha(\mathrm{H}), 21 \beta(\mathrm{H})-28,30$-bisnorhopane peak (described in the caption of Fig. 6).

Comparison on the basis of the ${ }^{13} \mathrm{C} /{ }^{12} \mathrm{C}$ ratios of the saturated and aromatic hydrocarbon fractions supports the interpretations based on the biological marker compounds. The hydrocarbon fractions of the asphalt and oil-stained rock are isotopically unlike the comparable hydrocarbons in the unstained, immature bituminous limestones (Fig. 10). In addition, when the $\delta^{13} \mathrm{C}$ of the asphalt and oil-stained rock hydrocarbons are compared with $\delta^{13} \mathrm{C}$ values for an IXTOC-I oil (Sweeney et al., 1980), the Challenger Knoll oil (DSDP Site 2, Leg 1) (Davis and Bray, 1969), and a Sunniland field oil (Palacas, 1983), the close similarity to Sunniland oil of the South Florida basin is confirmed.

These relationships suggest that the altered oils (asphalt and oil stains) have at least two possible sources. First, they may have been derived from shallow-water platform carbonate rocks of the same type that have been confirmed as the source of the South Florida basin oils of the Sunniland field trend (Palacas, 1983). Second, the source may be deep-water basinal facies that contain essentially the same type of hydrocarbon-generating organic matter as the shallow-water platform facies. In either case, the probable source is more thermally mature organic matter from stratigraphically equivalent rocks down-dip from Site 535, or from rocks stratigraphically below the Hauterivian and Valanginian sequence. The deeper and older rocks may include parts of the lowermost Cretaceous section or even the Jurassic section.

Compared with Sunniland oil (Fig. 11), the Site 535 asphalt and adjacent oil stains appear to be an altered oil residue, lacking or diminished in lower-molecularweight components and $n$-alkanes. Secondary alteration processes, such as inspissation, water-washing, and microbial degradation (Winters and Williams, 1969; Bailey et al., 1973), are commonly adduced to explain such changes in the gross composition of oils. In comparing the total alkane distribution of the asphalt and of the oil-stained samples (Fig. 11), the asphalt appears to be more severely degraded because it has lost the apparently original alkane components in the lower-molecular-weight range $\left(n-\mathrm{C}_{14}\right.$ to $\left.n-\mathrm{C}_{22}\right)$ that are still partially preserved in the oil-stained sample.

\section{ACKNOWLEDGMENTS}

We thank Sister Carlos M. Lubeck for providing the alkane extracts and capillary gas chromatographic analyses, and Charles $\mathrm{N}$. Threlkeld for the carbon isotope data. 

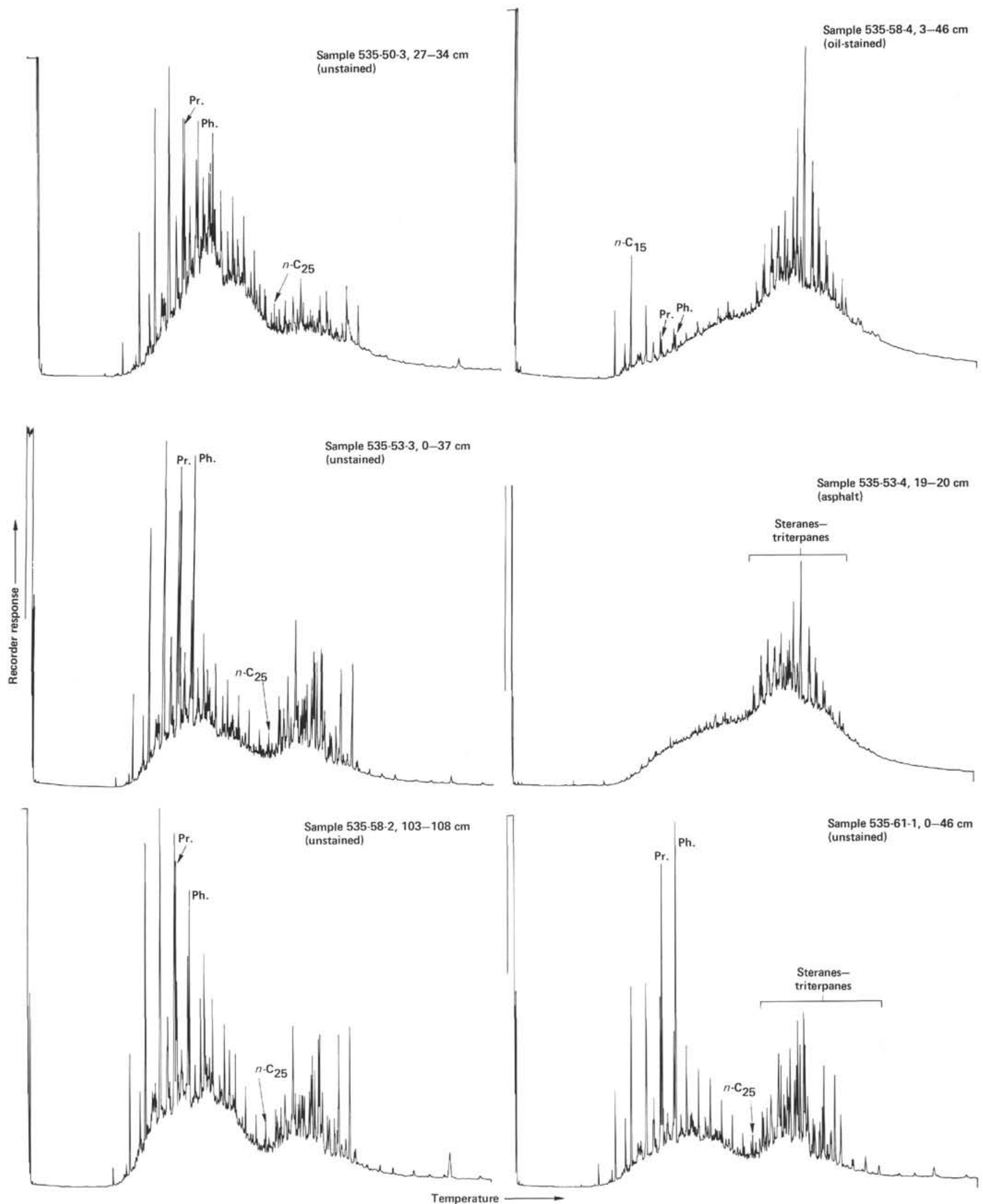

Figure 4. Capillary gas chromatograms of $\mathrm{C}_{15}$ alkane fractions isolated from four unstained limestone core samples, an oil-stained limestone sample, and an adjacent asphalt sample, Hole 535. Gas chromatographic conditions are described in the Experimental Procedures section. Stratigraphic positions of samples are shown in Figure 2. $\mathrm{Pr} .=$ pristane, $\mathrm{Ph} .=$ phytane. 


\section{REFERENCES}

Bailey, N. J. L., Jobson, A. M., and Rogers, M. A., 1973. Bacterial degradation of crude oil: comparison of field and experimental data. Chem. Geol., 11:203-221.
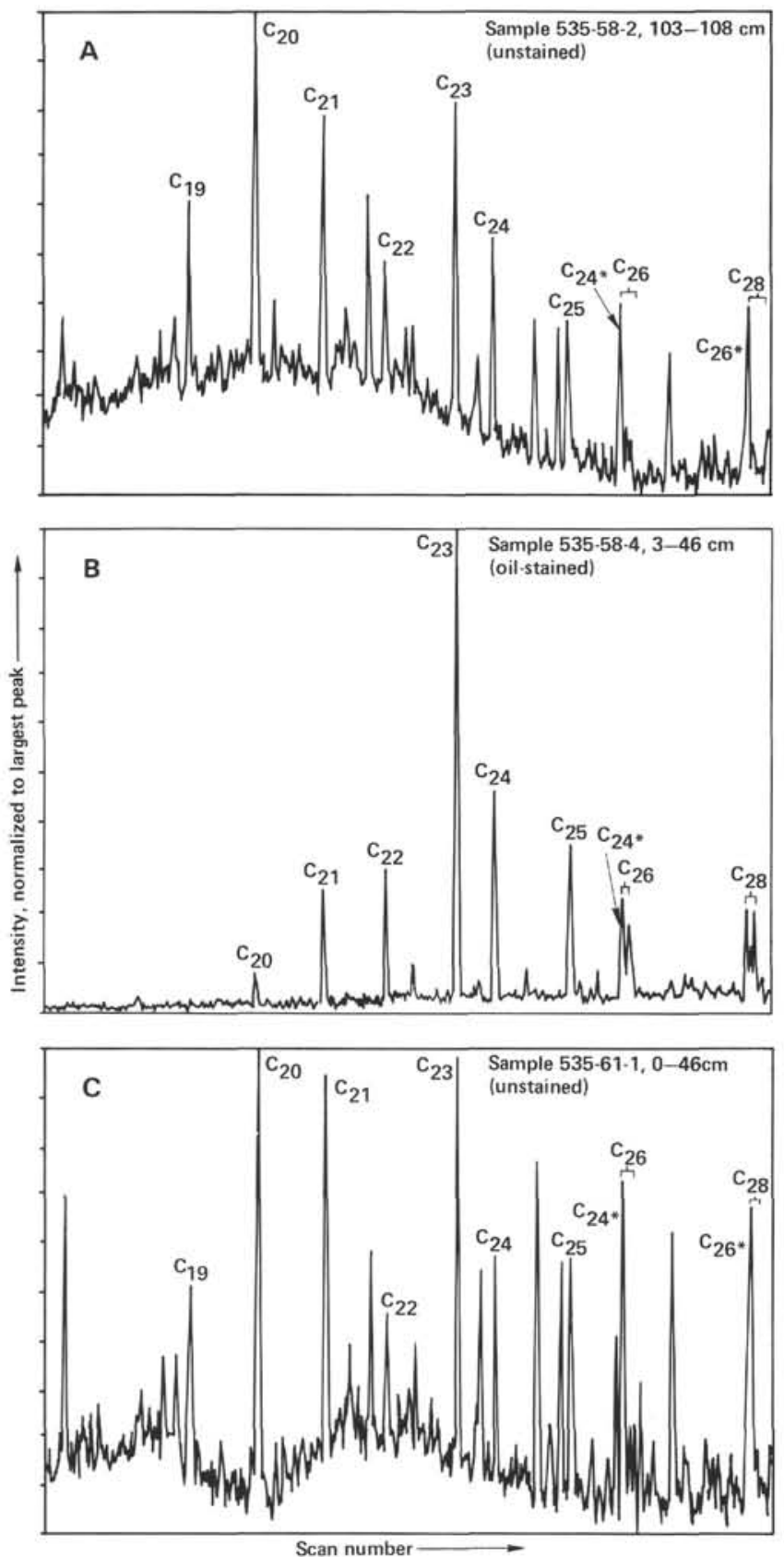

Figure 5. Tricyclic diterpane distributional patterns, as determined by the $m / z=191$ mass fragmentograms. A, C. The two unstained samples immediately above and below the oil-bearing samples. These patterns are also representative of the two topmost unstained samples. B. The pattern for the oil-stained sample. This pattern is also identical to that of the asphalt sample. The notations $\mathrm{C}_{19}$ to $\mathrm{C}_{28}$ indicate carbon numbers of homologous series of tricyclic diterpanes. In the two unstained samples, asterisks indicate $\mathrm{C}_{24}$ and $\mathrm{C}_{26}$ tetracyclic terpanes which, under the present GC conditions, coelute at the $\mathrm{C}_{26}$ and $\mathrm{C}_{28}$ tricyclic positions, respectively. Minor amounts of the $\mathrm{C}_{24}$ tetracyclic component may be present at the $\mathrm{C}_{26}$ tricyclic position in the oil-stained sample.
Barnes, P. J., Brassell, S. C., Comet, P., Eglinton, G., McEvoy, J., Maxwell, J. R., Wardroper, A. M. K., and Volkman, J. K., 1979. Preliminary lipid analyses of core sections 18,24 , and 30 from Hole 402A. In Montadert, L., Roberts, D. G., et al., Init. Repts. DSDP, 48:Washington (U.S. Govt. Printing Office), 965-976.

Comet, P. A., McEvoy, J., Brassell, S. C., Eglinton, G., Maxwell, J. R., and Thomson, I. D., 1981. Lipids of an upper Albian limestone, Deep Sea Drilling Project Site 465, Section 465A-38-3. In Thiede, J., Vallier, T. L., et al., Init. Repts. DSDP, 62:Washington (U.S. Govt. Printing Office), 923-937.

Davis, J. B., and Bray, E. E., 1969. Analyses of oil and cap rock from Challenger (Sigsbee) Knoll. In Ewing, M., Worzel, J. L., et al., Init. Repts. DSDP, 1:Washington (U.S. Govt. Printing Office), 415-500.

Dean, W. E., Claypool, G. E., and Thiede, J., 1981. Origin of organic-carbon-rich mid-Cretaceous limestones, mid-Pacific Mountains and Southern Hess Rise. In Thiede, J., Vallier, T. L., et al., Init. Repts. DSDP, 62:Washington (U.S. Govt. Printing Office), 877-890.

Ensminger, A., Albrecht, P., Ourisson, G., and Tissot, B., 1977. Evolution of polycyclic alkanes under the effect of burial (early Toarcian shales, Paris Basin). In Campos, R. and Goni, J. (Eds.), Advances in Organic Geochemistry 1975: Madrid, Spain (Enadisma), pp. $45-52$.

Giger, W., and Schaffner, C., 1981. Unsaturated steroid hydrocarbons as indicators of diagenesis in immature Monterey shales. Naturwissenschaften, 68:37-39.

Katz, B. J., 1982. Evidence for migration along fractures within a finegrained carbonate rock. Am. Assoc. Petrol. Geol. Bull., 66:587. (Abstract)

Mackenzie, A. S., Maxwell, J. R., Coleman, M. L., and Deegan, C. E., 1983. Biological marker and isotope studies of North Sea crude oils and sediments. Preprint 11th World Petrol. Congr., PD1: Origin, Migration, and Accumulation of Hydrocarbons.

Moldowan, J. M., Seifert, W. K., and Gallegos, E. J., 1983. Identification of an extended series of tricyclic terpanes in petroleum. Geochim. Cosmochim. Acta., 47:1531-1534.

Palacas, J. G., 1983. Carbonate rocks as sources of petroleum: geological and chemical characteristics and oil-source correlations. Preprint 11th World Petrol. Congr. PD1: Origin, Migration, and Accumulation of Hydrocarbons.

Rubenstein, I., Sieskind, O., and Albrecht, P., 1975. Rearranged sterenes in a shale: occurrence and simulated formation. J. Chem. Soc. Perkin Trans. 1, pp. 1833-1836.

Rullkötter, J., Leythaeuser, D., and Wendisch, D., 1982. Novel 23, 28bisnorlupanes in Tertiary sediments. Widespread occurrence of nuclear demethylated triterpanes. Geochim. Cosmochim. Acta., 46: 2501-2509.

Seifert, W. K., and Moldowan, J. M., 1980. The effect of thermal stress on source-rock quality as measured by hopane stereochemistry. In Douglas, A. G., and Maxwell, J. R. (Eds.), Advances in Organic Geochemistry 1979: Oxford (Pergamon Press), pp. 229-237.

1981. Paleoreconstruction by biological markers. Geochim. Cosmochim. Acta., 45:783-794.

Seifert, W. K., Moldowan, J. M., Smith, G. W., and Whitehead, E. V., 1978. First proof of structure of a $C_{28}$-pentacyclic triterpane in petroleum. Nature, 271:436-437.

Sweeney, R. E., Haddad, R. I., and Kaplan, I. R., 1980. Tracing the dispersal of the IXTOC-I oil using C, H, S, and N stable isotope ratios. Proc. Prelim. Results Sept. 1979 Researcher/Pierce IXTOC-1 Cruise (Boulder, National Oceanic and Atmospheric Admin.), pp. 89-115.

Winters, J. C., and Williams, J. A., 1969. Microbiological alteration of crude oil in the reservoir. Symp. Petrol. Trans. Geol. Environ. (Div. Petrol. Chem., Am. Chem. Soc.), Paper PETR 86, pp. E22-E31.

Date of Initial Receipt: January 20, 1983

Date of Acceptance: July 25, 1983 

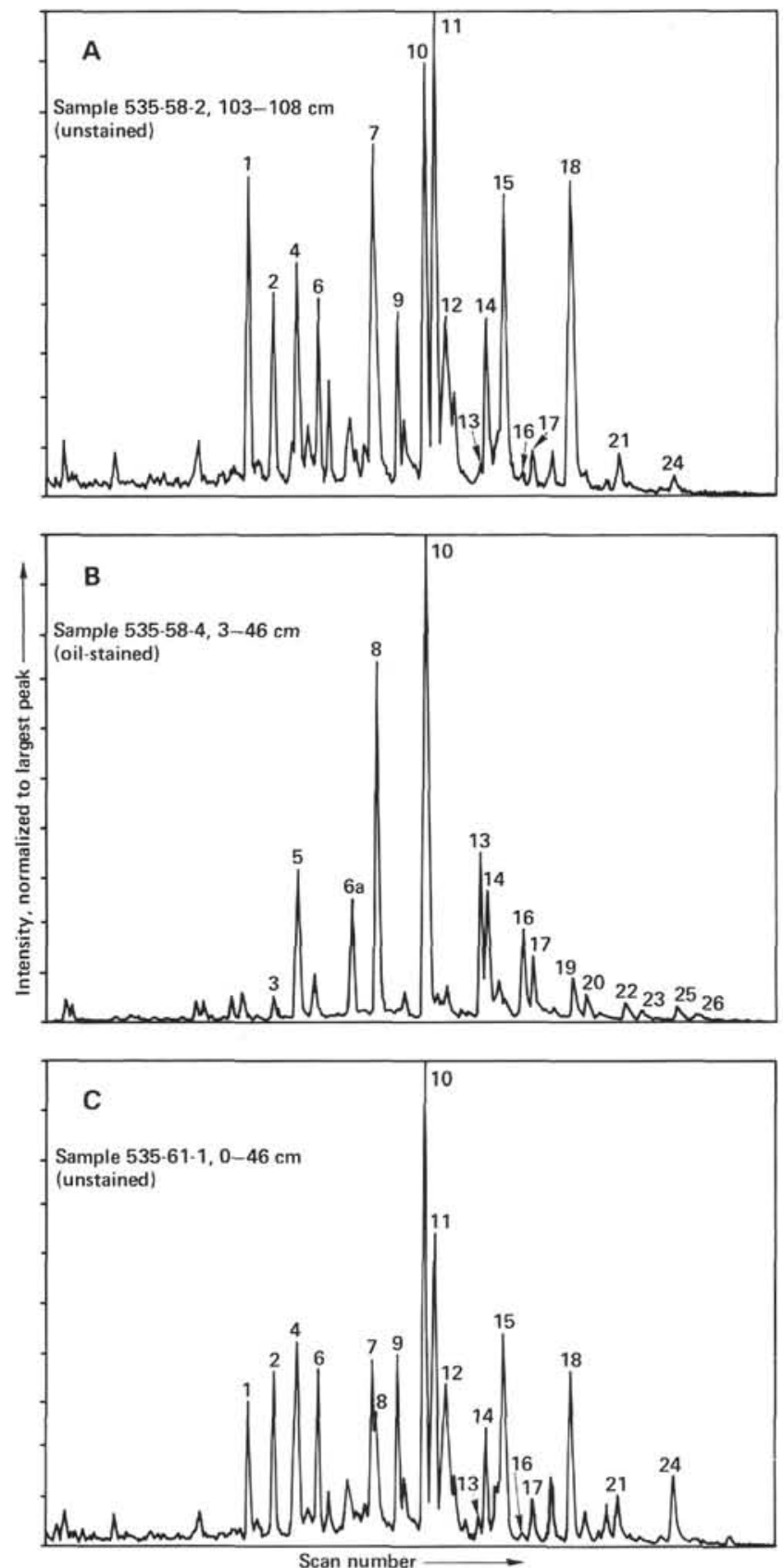

Figure 6. Pentacyclic triterpane distributional patterns, as determined by $m / z=191$ mass fragmentograms for the same samples shown in Figure 5. Numbered peaks are identified in Table 3. A,C. Unstained samples. B. Oil-stained sample. Peak "6a" in the oilstained sample is tentatively identified as $17 \alpha(\mathrm{H}), 18 \alpha(\mathrm{H}), 21 \beta(\mathrm{H})$ 28,30 -bisnorhopane, which is technically a nuclear-demethylated triterpane (i.e., the methyl group at the $\mathrm{C}_{18}$ position in the pentacyclic nucleus is missing). This compound is not as ubiquitous in crude oils as some other compounds in the hopane series, such as norhopane and hopane, but it has been found in numerous sediments and a few oils worldwide, predominantly Tertiary and younger (Rullkötter et al., 1982). Like other nuclear-demethylated triterpanes, $17 \alpha(\mathrm{H}), 18 \alpha(\mathrm{H}), 21 \beta(\mathrm{H})-28,30$-bisnorhopane, where it is present, often occurs in large abundance relative to the other saturated hydrocarbons (Rullkötter et al., 1982). One striking example is in the Monterey Shale, offshore California, where it may make up as much as $26 \mathrm{ppm}$ of the whole rock (Seifert et al., 1978).
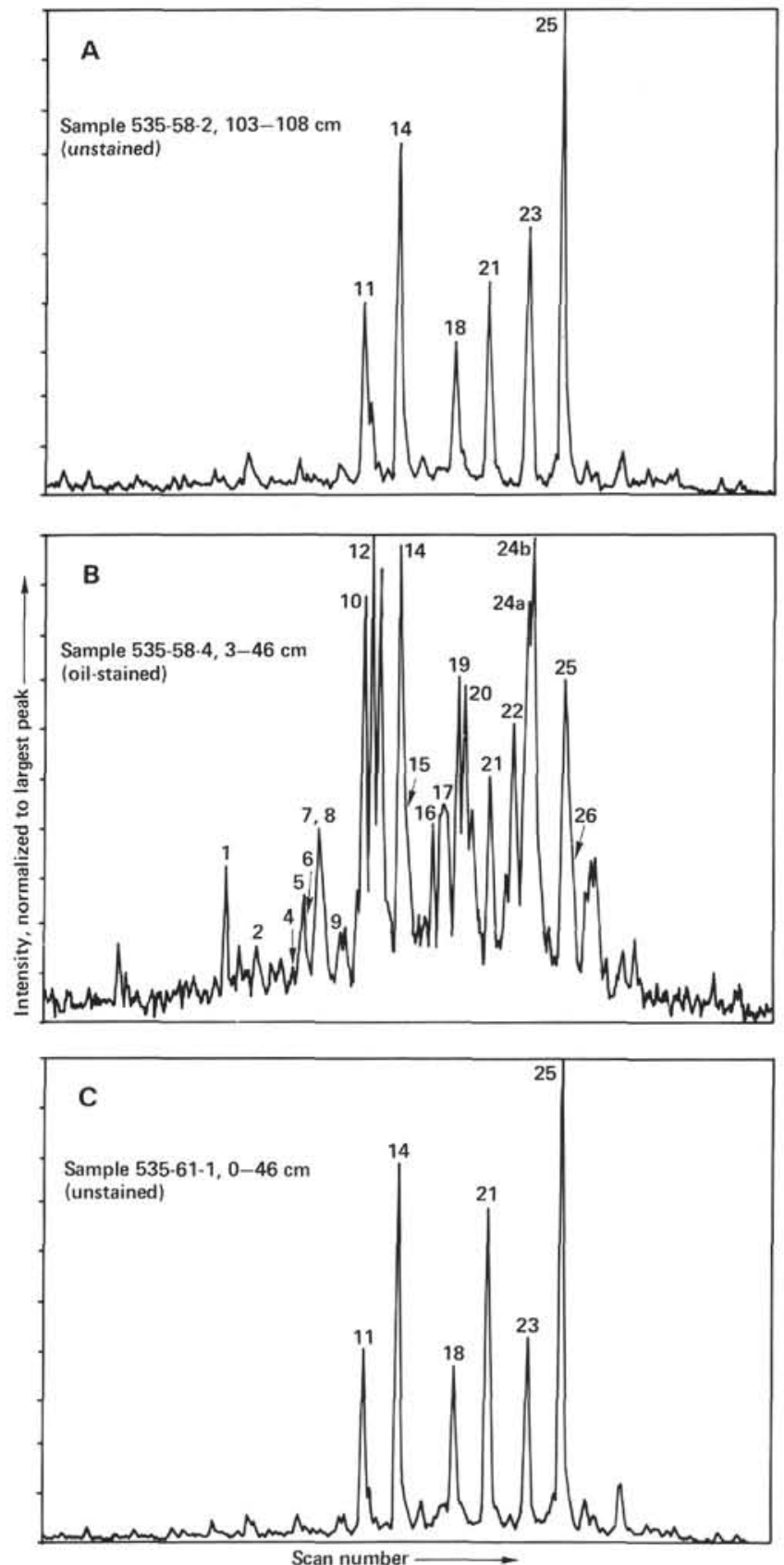

Figure 7. Sterane distributional patterns as determined by $m / z=217$ mass fragmentograms for the same samples shown in Figures 5 and 6. Numbered peaks are identified in Table 4. A,C. Unstained samples. B. Oil-stained samples. 
Table 3. List of identified pentacyclic triterpanes and related compounds.

\begin{tabular}{|c|c|c|c|}
\hline Peak $^{\mathrm{a}}$ & $\begin{array}{c}\text { Assignment }{ }^{b} \\
\text { (carbon number-name) }\end{array}$ & Peak $^{\mathrm{a}}$ & $\begin{array}{c}\text { Assignment } \\
\text { (carbon number-name) }\end{array}$ \\
\hline 1 & $\mathrm{C}_{27}$-trisnorhopene & 14 & $\mathrm{C}_{31}-22 \mathrm{R}$ homohopane \\
\hline 2 & $\mathrm{C}_{30}$-non-hopanoid & 15 & $\mathrm{C}_{30}-17 \beta(\mathrm{H}), 21 \beta(\mathrm{H})$ hopane \\
\hline 3 & $\mathrm{C}_{27}-18 \alpha(\mathrm{H})$ trisnorhopane & 16 & $\mathrm{C}_{32}-22 \mathrm{~S}$ bishomohopane \\
\hline 4 & $\mathrm{C}_{30}$-non-hopanoid & 17 & $\mathrm{C}_{32}-22 \mathrm{R}$ bishomohopane \\
\hline 5 & $\mathrm{C}_{27}-17 \alpha(\mathrm{H})$ trisnorhopane & 18 & $\mathrm{C}_{31^{-17}}(\mathrm{H}), 21 \beta(\mathrm{H})$ homohopane \\
\hline 6 & $\mathrm{C}_{30}$-non-hopanoid & 19 & $\mathrm{C}_{33}-22 \mathrm{~S}$ trishomohopane \\
\hline $6 \mathbf{a}$ & $17 \alpha(\mathrm{H}), 18 \alpha(\mathrm{H}), 21 \beta(\mathrm{H})-28,30$-bisnorhopane & 20 & $\mathrm{C}_{33}-22 \mathrm{R}$ trishomohopane \\
\hline 7 & $\mathrm{C}_{30}$-hopene & 21 & $C_{32}-17 \beta(\mathrm{H}), 21 \beta(\mathrm{H})$ bishomohopane \\
\hline 8 & $\mathrm{C}_{29}$-norhopane & 22 & $\mathrm{C}_{34}-22 \mathrm{~S}$ tetrakishomohopane \\
\hline 9 & $\mathrm{C}_{30}$-hopene & 23 & $\mathrm{C}_{34}-22 \mathrm{R}$ tetrakishomohopane \\
\hline 10 & $\mathrm{C}_{30^{-17} \alpha(\mathrm{H}), 21 \beta(\mathrm{H}) \text { hopane }}$ & 24 & $\mathrm{C}_{33}-17 \beta(\mathrm{H}), 21 \beta(\mathrm{H})$ trishomohopane \\
\hline 11 & $\mathrm{C}_{30}$-hopene & 25 & $\mathrm{C}_{35}-22 \mathrm{~S}$ pentakishomohopane \\
\hline 12 & $\left.\mathrm{C}_{30^{-17}}-\mathrm{H}\right), 21 \alpha(\mathrm{H})$ moretane & 26 & $\mathrm{C}_{35}-22 \mathrm{R}$ pentakishomohopane \\
\hline 13 & $\mathrm{C}_{31}-22 \mathrm{~S}$ homohopane & & \\
\hline
\end{tabular}

${ }^{a}$ Peak numbers refer to Figure 6 and to pentacyclic and combined tricyclic-pentacyclic distributions of

b Figure 9 .

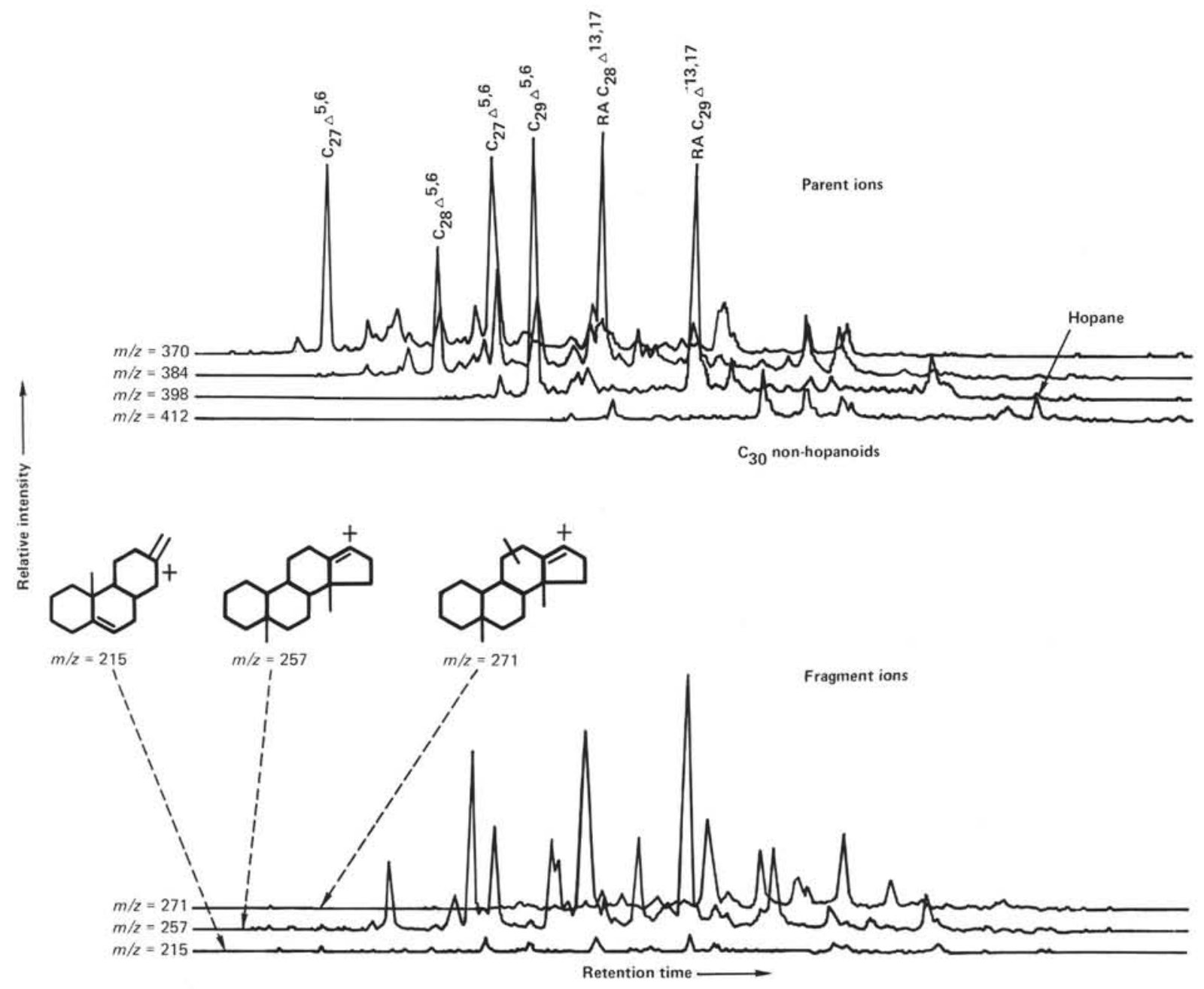

Figure 8. Sterene distributional patterns of a typical unstained limestone sample (535-58-2,103-108 cm), as determined by parent-ion chromatograms and diagnostic-ion mass fragmentograms. Although not shown here, analyses showed that comparable sterenes in the oil-stained $(535-58-4,3-46 \mathrm{~cm})$ and asphalt $(535-58-4,19-20 \mathrm{~cm})$ samples are essentially absent. RA $=$ rearranged sterenes. 
Hole 535, oil-stained limestone

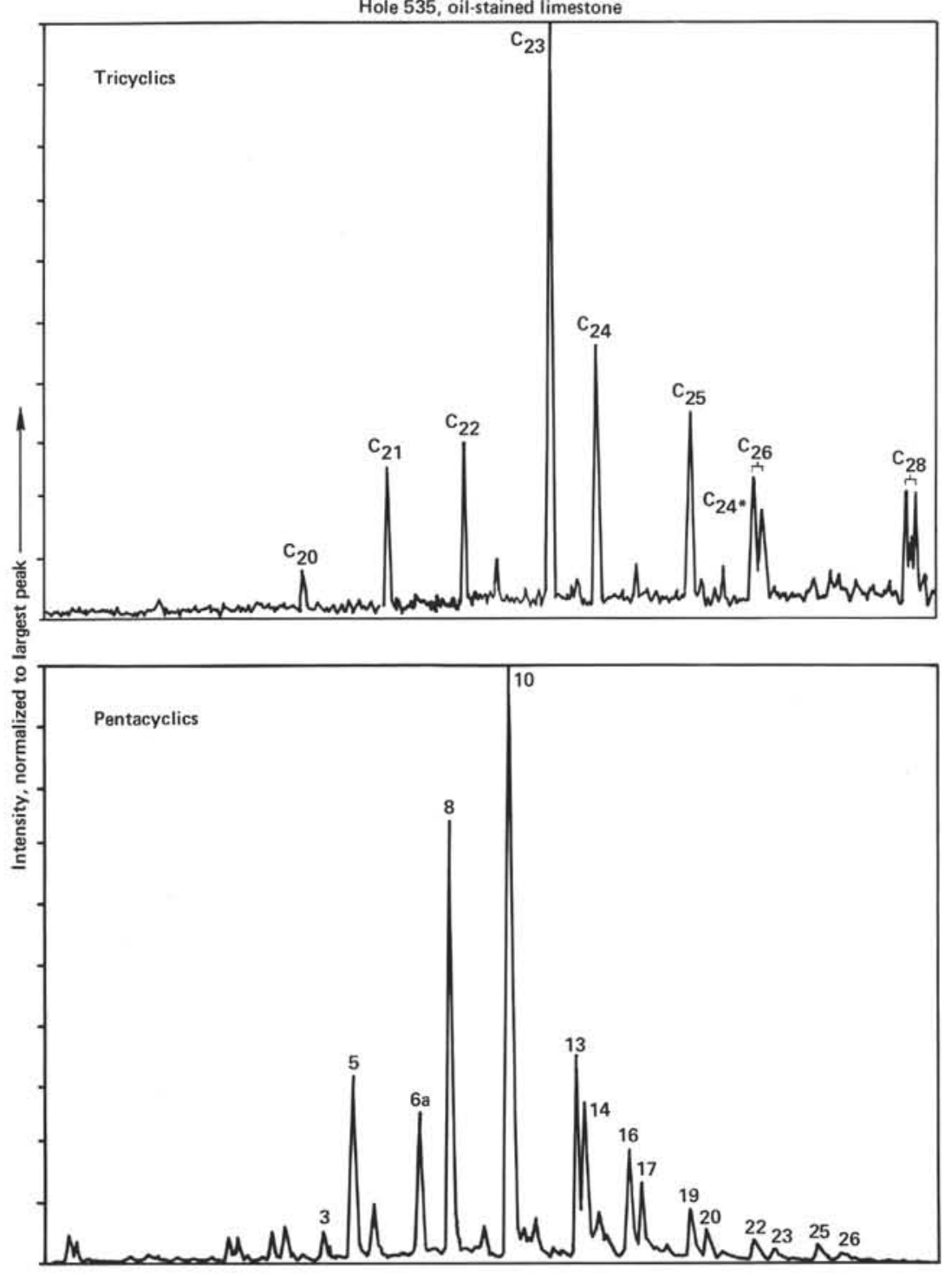

Sunniland crude oil, South Florida
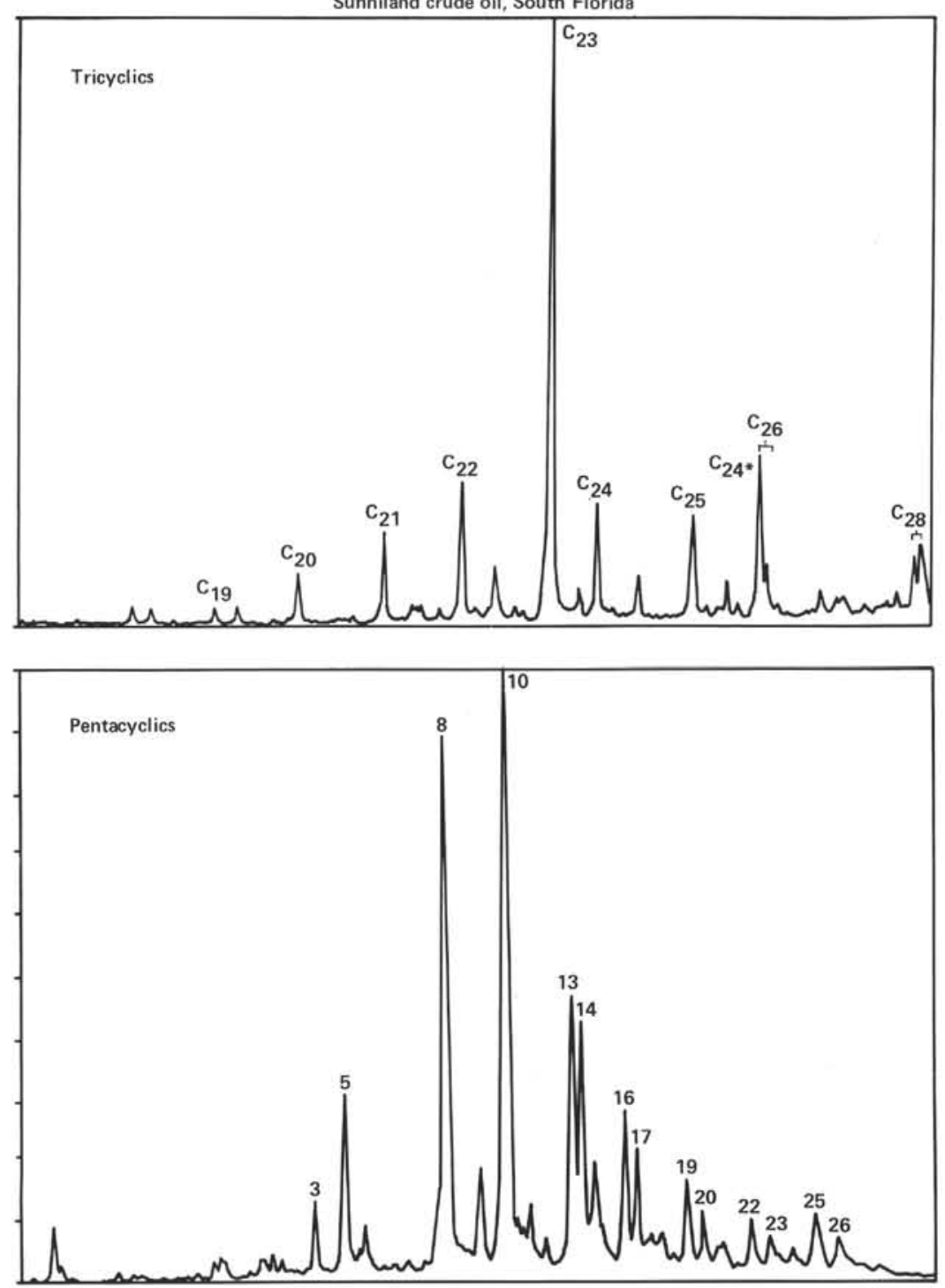

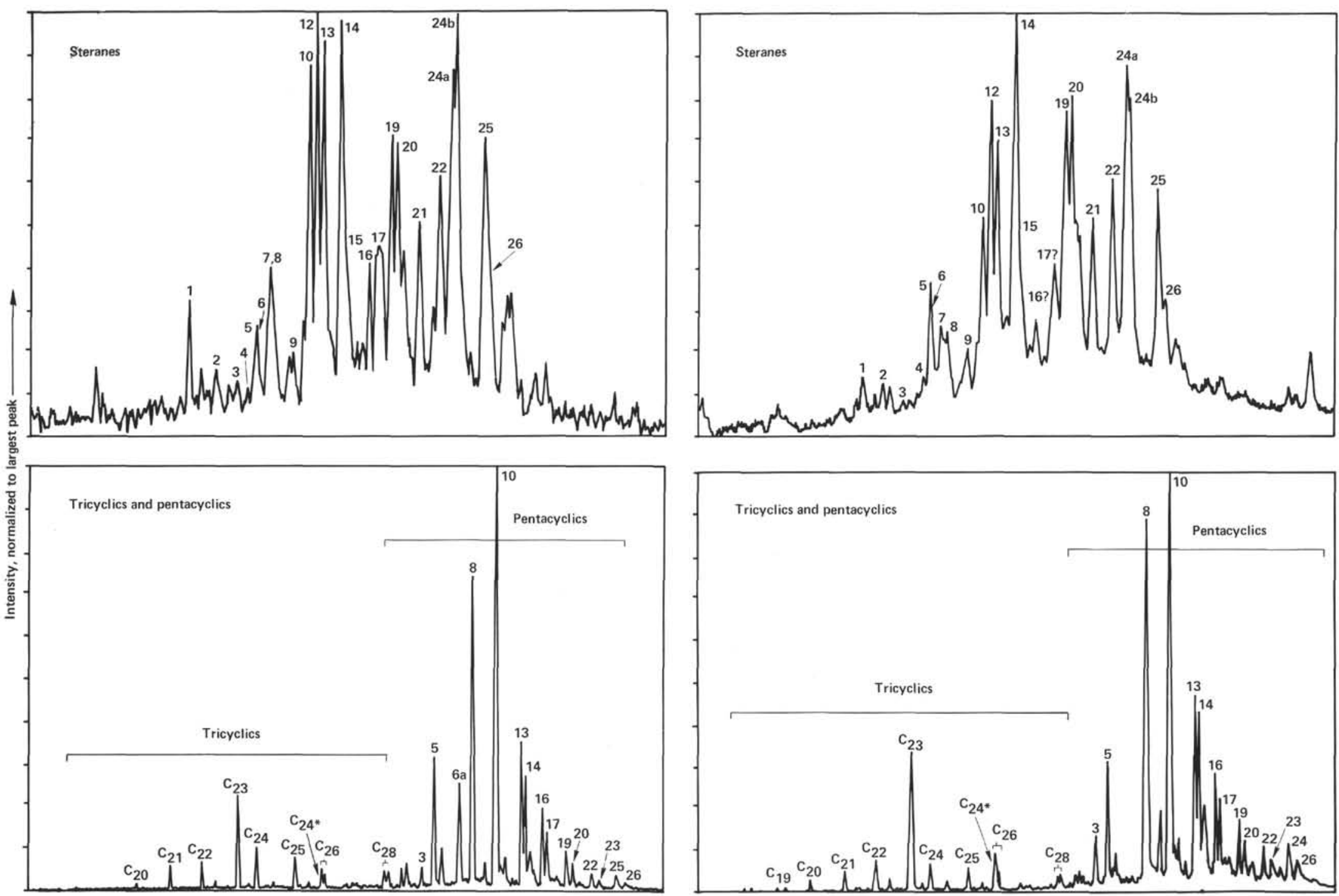

Figure 9. Comparison of tricyclic, pentacyclic, sterane, and combined tricyclic-pentacyclic patterns, as determined by mass fragmentography of an oil-stained limestone sample ( 535 $58-4,3-46 \mathrm{~cm}$ ) and a lower Sunniland crude oil (Lower Cretaceous) from South Florida. Although all biomarker patterns are in general comparable-except for some minor differences in ratios of adjoining peaks, indicating similar organic matter source types-the most apparent significant difference between the Site 535 oil and the Sunniland crude oil is the presence of a prominent nuclear-demethylated triterpane $(17 \alpha(\mathrm{H}), 18 \alpha(\mathrm{H}), 21 \beta(\mathrm{H})-28,30$-bisnorhopane; peak $6 \mathrm{a})$ in the pentacyclic distribution in the Site 535 oil-stained sample (see caption of Fig. 6 for further information on peak 6a). This compound, abundant in the Monterey Shale, suggests that the carbonate facies that yielded the oil in the asphalt and adjacent oil stain, besides being similar to the carbonate source-facies in South Florida, may also contain some of the same type of organic matter or microbiologic assemblage that is peculiar to the Monterey Shale. Interestingly, the $17 \alpha(\mathrm{H}), 18 \alpha(\mathrm{H}), 21 \beta(\mathrm{H})-28,30$-bisnorhopane component has not been observed in any of the oil or rock samples through- 
Table 4. List of identified steranes.

\begin{tabular}{|c|c|c|c|}
\hline Peak & Assignment & Peak & Assignment \\
\hline 1 & $13 \beta(\mathrm{H}), 17 \alpha(\mathrm{H}) \mathrm{RA} \mathrm{C} 27$ & 14 & $5 \alpha(\mathrm{H}), 14 \alpha(\mathrm{H})$ REG $\mathrm{C}_{27}(20 \mathrm{R})$ \\
\hline 2 & $13 \beta(\mathrm{H}), 17 \alpha(\mathrm{H}) \mathrm{RA} \mathrm{C}_{27}$ & 15 & $13 \beta(\mathrm{H}), 17 \alpha(\mathrm{H}) \mathrm{RA} \mathrm{C}_{29}$ \\
\hline 3 & $13 \alpha(\mathrm{H}), 17 \beta(\mathrm{H}) \mathrm{RA} \mathrm{C}_{27}$ & 16 & $13 \beta(\mathrm{H}), 17 \alpha(\mathrm{H}) \mathrm{RA} \mathrm{C} 29$ \\
\hline 4 & $13 \alpha(\mathrm{H}), 17 \beta(\mathrm{H}) \mathrm{RA} \mathrm{C}_{27}$ & 17 & $5 \alpha(\mathrm{H}), 14 \alpha(\mathrm{H})$ REG C $28(20 \mathrm{~S})$ \\
\hline 5 & $13 \beta(\mathrm{H}), 17 \alpha(\mathrm{H})$ RA C 28 & 18 & $5 \beta(\mathrm{H}), 14 \alpha(\mathrm{H}) \mathrm{REG} \mathrm{C}_{28}$ \\
\hline 6 & $13 \beta(\mathrm{H}), 17 \alpha(\mathrm{H}) \mathrm{RA} \mathrm{C}_{28}$ & 19 & $5 \alpha(\mathrm{H}), 14 \beta(\mathrm{H}) \mathrm{REG} \mathrm{C}_{28}(20 \mathrm{R}$ \\
\hline 7 & $5 \alpha(\mathrm{H}), 14 \beta(\mathrm{H})$ REG $C_{27}$ & 20 & $5 \alpha(\mathrm{H}), 14 \beta(\mathrm{H})$ REG C $28(20 \mathrm{~S})$ \\
\hline 8 & $13 \alpha(\mathrm{H}), 17 \beta(\mathrm{H})$ RA C 28 & 21 & $5 \alpha(\mathrm{H}), 14 \alpha(\mathrm{H})$ REG C $28(20 \mathrm{R})$ \\
\hline 9 & $13 \beta(\mathrm{H}), 17 \alpha(\mathrm{H}) \mathrm{RA} \mathrm{C} 28$ & 22 & $5 \alpha(\mathrm{H}), 14 \alpha(\mathrm{H})$ REG C $29(20 \mathrm{~S})$ \\
\hline 10 & $5 \alpha(\mathrm{H}), 14 \alpha(\mathrm{H})$ REG C $27(20 \mathrm{~S})$ & 23 & $5 \beta(\mathrm{H}), 14 \alpha(\mathrm{H})$ REG $\mathrm{C}_{29}$ \\
\hline 11 & $5 \beta(\mathrm{H}), 14 \alpha(\mathrm{H})$ REG C 27 & $24 a$ & $5 \alpha(\mathrm{H}), 14 \beta(\mathrm{H})$ REG C $29(20 \mathrm{R}$ \\
\hline \multirow[t]{2}{*}{12} & $13 \beta(\mathrm{H}), 17 \alpha(\mathrm{H}) \mathrm{RA} \mathrm{C}_{29}$ & $24 \mathrm{~b}$ & $5 \alpha(\mathrm{H}), 14 \beta(\mathrm{H})$ REG $\mathrm{C}_{29}(20 \mathrm{~S})$ \\
\hline & $\left.5 \alpha(\mathrm{H}), 14 \beta(\mathrm{H}) \mathrm{REG} \mathrm{C}_{27}(20 \mathrm{R})\right\}$ & 25 & $5 \alpha(\mathrm{H}), 14 \alpha(\mathrm{H}) \mathrm{REG} \mathrm{C}_{29}(20 \mathrm{R})$ \\
\hline 13 & $5 \propto(\mathrm{H}), 14 \beta(\mathrm{H})$ REG $\mathrm{C}_{27}(20 \mathrm{~S})$ & 26 & $13 \alpha(\mathrm{H}), 17 \beta(\mathrm{H}) \mathrm{RA} C_{29}$ \\
\hline
\end{tabular}

Note: Peak numbers refer to Figure 7 and to sterane distributions in Figure 9. Assignments are based on mass spectral interpretation, multiple ion detection, and GC retention times. $\mathrm{REG}=$ regular steranes; $\mathrm{RA}=$ rearranged steranes (diasteranes).

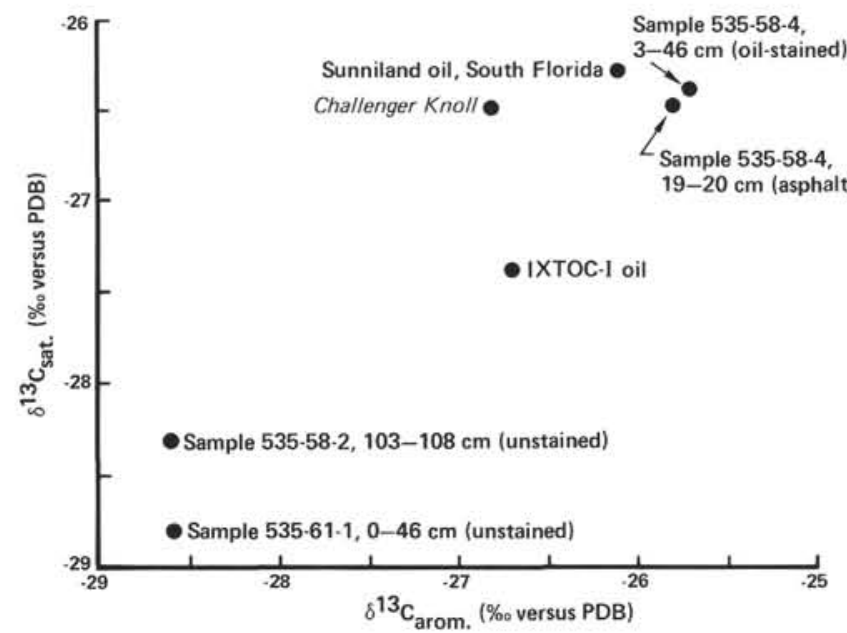

Figure 10. Plot of carbon isotope data (from Table 2) of saturated hydrocarbons versus aromatic hydrocarbons for the oil-stained and asphalt samples $(535-58-4,3-46 \mathrm{~cm}$ and $535-58-4,19-20 \mathrm{~cm}$, respectively) and two representative unstained samples (535-58-2, $103-108 \mathrm{~cm}$ and $535-61-1,0-46 \mathrm{~cm}$ ) collected from Hole 535. For comparison, data are also included for an oil extract from a Jurassic cap rock on top of the Challenger Knoll at DSDP Site 2; from a typical Sunniland crude oil from the Sunniland field in South Florida; and from a representative oil sample from the IXTOC-I well in the Bay of Campeche off the coast of Mexico. The IXTOC-I well was the site of a major, uncontrollable oil blowout in June 1979. Source locations of the three oil samples are shown in Figure 1.
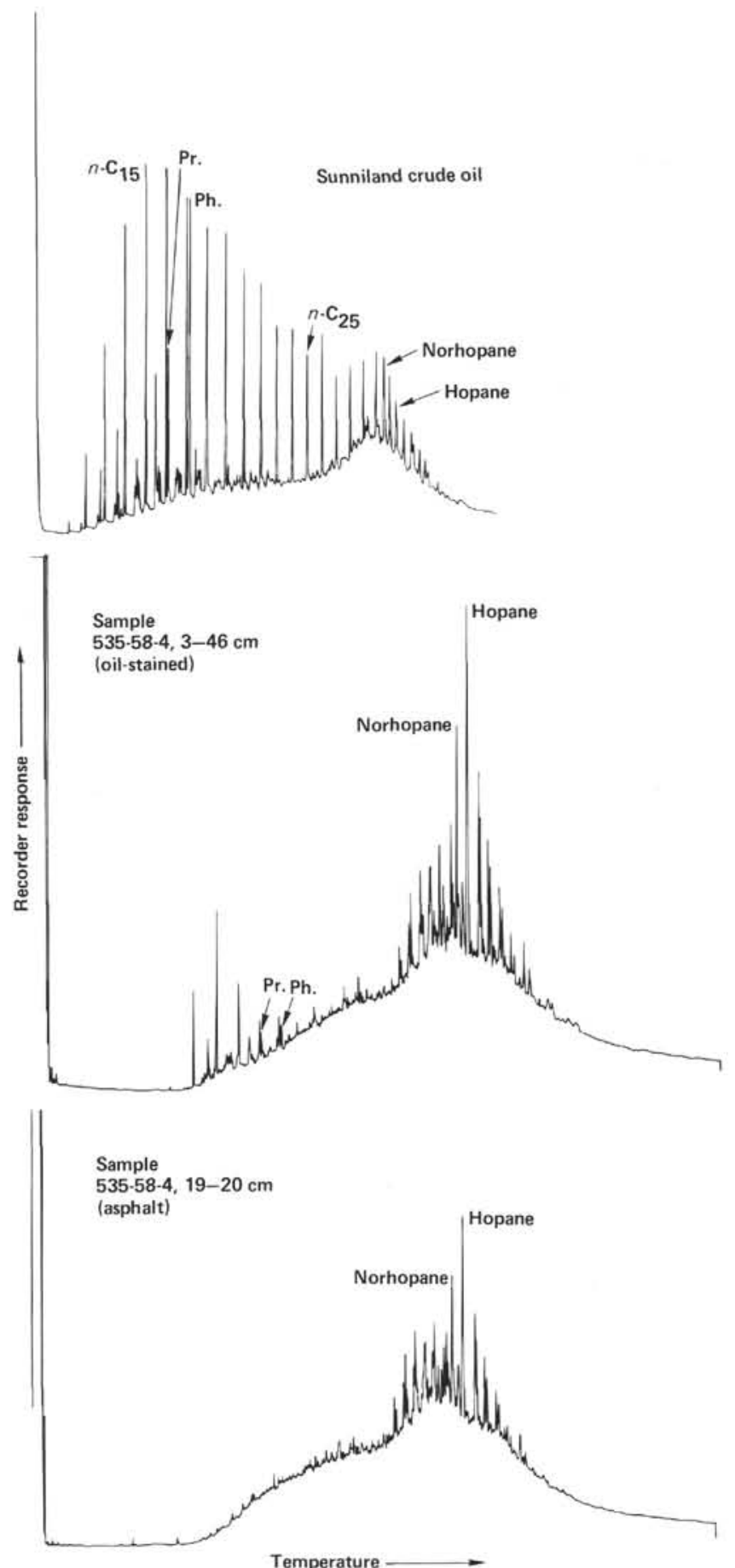

Figure 11. Comparison of the $\mathrm{C}_{15+}$ alkane distribution of the oilstained and asphalt samples from Hole 535 and a typical Sunniland crude oil from South Florida. The oil in the Hole 535 samples is believed to have been derived from a carbonate source-rock facies roughly similar to that which yielded the Sunniland-type crude oil. Post-migration processes such as inspissation and biodegradation are believed responsible for the nearly total or partial removal of the $n$-alkane components that project above the hump (unidentified branched-cyclic compounds) in the asphalt and oil-stained samples, respectively. $\mathrm{Pr} .=$ pristane, $\mathrm{Ph} .=$ phytane. 